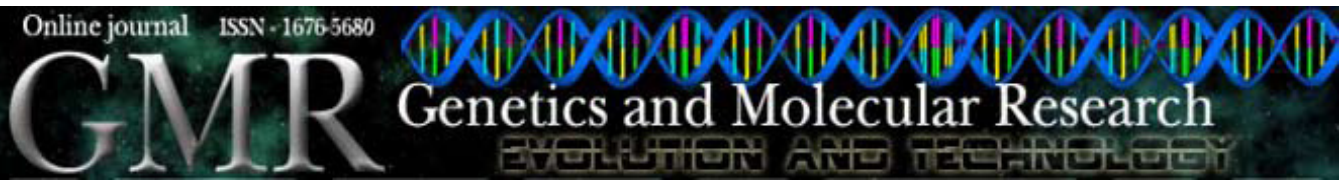

\title{
A rapid and efficient method for isolation of total RNA from Euglena gracilis (Euglenoidea)
}

\author{
D. González-Mendoza ${ }^{1}$, A. Morales-Trejo ${ }^{1}$ and H. Brito-Vera ${ }^{2}$ \\ ${ }^{1}$ Instituto de Ciencias Agrícolas, Universidad Autónoma de Baja California, \\ Baja California, México \\ ${ }^{2}$ Universidad Juárez Autónoma de Tabasco, Tabasco, México \\ Corresponding author: D. González-Mendoza \\ E-mail: daniasaf@gmail.com
}

Genet. Mol. Res. 8 (2): 482-486 (2009)

Received January 26, 2009

Accepted March 11, 2009

Published April 28, 2009

\begin{abstract}
RNA isolation is essential to the study of gene expression at the molecular level. However, it is difficult to isolate RNA from organisms that contain large amounts of polysaccharides or other compounds that bind or coprecipitate with RNA, such as the unicellular protist Euglena gracilis. Currently, there is no commercial kit available that is specific for the isolation of high-quality RNA from this organism. Since it contains large amount of polysaccharides, the common protocols for RNA isolation usually result in poor yields when applied to $E$. gracilis. We developed a simple and fast RNA protocol that effectively removes these contaminating substances, without affecting the RNA yield. This protocol was based on the sodium dodecyl sulfate/phenol method, without $\beta$-mercaptoethanol and without maceration in liquid nitrogen; it uses phenol/chloroform extraction to remove proteins, DNA, and co-precipitated polysaccharides. The RNA isolated by this protocol is of sufficient quality for molecular applications; this technique could be applied to other organisms that have similar substances that hinder RNA extraction.
\end{abstract}

Key words: Euglena gracilis; Sodium dodecyl sulfate-Tris;

RNA isolation; Reverse transcription-polymerase chain reaction 


\section{INTRODUCTION}

Euglenoids are among the most ancient of the free-living eukaryotic protists, and are one of the earliest lineages to contain mitochondria. Although possessing the unique characteristic of being neither plants nor animals, euglenoids are poorly known despite being ubiquitous in fresh water, marine water, and soil habitats. A greater knowledge of euglenoids is crucial because of the ecological importance of these organisms. Members of the genus Euglena, especially E. gracilis, have been some of the most widely used single-cell eukaryotes for physiological and biochemical studies, and can be used to indicate the health of their environment (RodríguezZavala et al., 2007). These characteristics have prompted studies focused on understanding the physiological mechanisms of tolerance to heavy metal stress at the molecular level. Nevertheless, for the study of gene expression in E. gracilis, the isolation of pure RNA is crucial, because it is a pre-requisite for diverse molecular techniques such as isolating genes by RT-PCR (reverse transcription coupled with polymerase chain reaction) or investigating gene expression profiles, Southern blot analysis and the construction of gene libraries. The isolation of RNA from E. gracilis can be difficult and often requires modifications of existing protocols. Although there have been some reports on total RNA isolation from Euglena spp (MacDonald et al., 1987), an optimized protocol providing high quantities of pure total RNA for gene expression studies is lacking. In the present study, an easy and rapid protocol was developed for the isolation of enough good-quality total RNA from small amounts of biomass of E. gracilis (Krebs) strain Z.

\section{MATERIAL AND METHODS}

\section{Cultivation and growth conditions}

Euglena gracilis Krebs (strain Z) was grown to the mid-logarithmic phase (3-5 days) under photoheterotrophic conditions, using 12/12-h light-dark cycles with fluorescent white light $\left(60-70 \mu \mathrm{mol}\right.$ quanta $\left.\mathrm{m}^{-2} \mathrm{~s}^{-1}\right)$ at $26^{\circ} \mathrm{C}$ in Hutner medium (Hutner et al., 1956). Aliquots (1 $\mathrm{mL})$ were taken from cell cultures and cells were harvested by centrifugation $(6000 \mathrm{~g}$, at room temperature for $2 \mathrm{~min}$ ). Samples were stored at $-80^{\circ} \mathrm{C}$ until use.

\section{RNA extraction buffer and solutions}

The tubes and bottles were treated with $0.1 \%$ DEPC solution at $37^{\circ} \mathrm{C}$ overnight, autoclaved twice at $121^{\circ} \mathrm{C}$ for $20 \mathrm{~min}$, and then dried at $100^{\circ} \mathrm{C}$ before use. The tips used in RNA extraction were RNase-free and DNase-free and purchased from Axygen, USA. The extraction buffer was $3 \%$ sodium dodecyl sulfate (SDS) (w/v) containing $0.5 \mathrm{mM}$ EDTA, $0.1 \mathrm{mM}$ Tris-HCl, $\mathrm{pH} 8.0$, and $0.1 \%$ DEPC (v/v), $\mathrm{pH} 8.0$. A chloroform/phenol $(1: 1, \mathrm{v} / \mathrm{v})$ mixture was also prepared for use. All buffers and solutions were incubated at $37^{\circ} \mathrm{C}$ overnight before autoclaving $\left(121^{\circ} \mathrm{C}, 20 \mathrm{~min}\right)$ twice.

\section{RNA extraction procedure}

A volume of $200 \mu \mathrm{L}$ extraction buffer was added to $10 \mathrm{mg}$ biomass of E. gracilis and shaken vigorously for $15 \mathrm{~s}$. Next, $200 \mu \mathrm{L}$ chloroform/phenol (1:1) was added care- 
fully and the mixture incubated at $65^{\circ} \mathrm{C}$ for $5 \mathrm{~min}$. Later, the homogenate was cooled to room temperature and centrifuged at $10,000 \mathrm{~g}$ at $4^{\circ} \mathrm{C}$ for $5 \mathrm{~min}$. The supernatant was transferred to a new tube, and one volume of chilled isopropanol or absolute ethanol was added, followed by thorough mixing to precipitate total RNA at $-20^{\circ} \mathrm{C}$ for $20 \mathrm{~min}$; the mixture was then centrifuged at $10,000 \mathrm{~g}$ for $10 \mathrm{~min}$. The pellet was washed with $75 \%$ ethanol twice and centrifuged at $10,000 \mathrm{~g}$ at $4{ }^{\circ} \mathrm{C}$ for $5 \mathrm{~min}$. The supernatant was discarded and the pellet was resuspended in $30 \mu \mathrm{L}$ DEPC-treated MiniQuantum water, and stored at $-80^{\circ} \mathrm{C}$ for further use. Concentration, yield, and quality control indices based on absorbance at 230,260 , and $280 \mathrm{~nm}\left(\mathrm{~A}_{260 / 280}\right.$ ratios and $\mathrm{A}_{260 / 230}$ ratios $)$ were determined with $2 \mu \mathrm{L}$ resuspended total RNA. A volume of $5 \mu \mathrm{L}$ of the total RNA solution was loaded on a $1 \%$ agarose gel, electrophoresed to separate RNA, stained with ethidium bromide, and visualized under UV light to check the size distribution of the total RNA and the integrity of ribosomal RNA bands.

\section{Reverse transcription-polymerase chain reaction}

Equal amounts of total RNA $(1 \mu \mathrm{g})$ were converted to single-strand cDNA using reverse transcriptase, and specific cDNA was amplified by PCR with Taq DNA polymerase according to manufacturer (Invitrogen, CA, USA) instructions. The synthesized cDNA was used for PCR amplifications using $18 S$ gene primers (Product Size: $300 \mathrm{bp}$, Ambion $^{\circledR}$ ). PCR program parameters were: $94^{\circ} \mathrm{C}$ for $2 \mathrm{~min}$, followed by 30 cycles of $1 \mathrm{~min}$ at $94^{\circ} \mathrm{C}$ for DNA denaturing, $1 \mathrm{~min}$ at $45^{\circ} \mathrm{C}$ for primer annealing, and $1 \mathrm{~min}$ at $72^{\circ} \mathrm{C}$ for extension. The program was terminated with a 5 min extension at $72^{\circ} \mathrm{C}$. The amplified products were separated on a $1.5 \%$ agarose gel and visualized by ethidium bromide staining, where $2 \mu \mathrm{L}$ of cDNA was used as PCR template.

\section{RESULTS AND DISCUSSION}

In the present study, a new protocol was developed to isolate enough good-quality total RNA from the biomass of E. gracilis. In this protocol, higher-strength SDS (3\%) was used as lysis buffer without $\beta$-mercaptoethanol because the amount of phenolic compounds in E. gracilis is not significant. Additionally, this method does not involve maceration in liquid nitrogen or additional lysis steps, such as mechanical disruption and enzymatic digestion.

In this study, RNA was extracted without degradation (Figure 1). In all lanes, 2 distinct bands corresponding to total RNA are clearly shown with no apparent degradation. The $\mathrm{A}_{260 / 280}$ was 1.8, suggesting that the RNA was pure and could be used for further analysis. In all samples, the $\mathrm{A}_{260 / 230}$ ratios were more than 1.9, suggesting low contamination by polysaccharides (data not shown). These results are important because the procedures for RNA isolation are usually evaluated by quantity, quality, and integrity of the RNA obtained. On the other hand, the purification with phenol/chloroform extraction was introduced to remove polysaccharides because phenol/chloroform extraction denatures RNases and removes proteins much more effectively than chloroform-only extraction (Wang et al., 2005). Additionally, the use of $100 \%$ isopropanol or ethanol facilitated the effective precipitation of RNA and rendered it more stable in the precipitated form. 


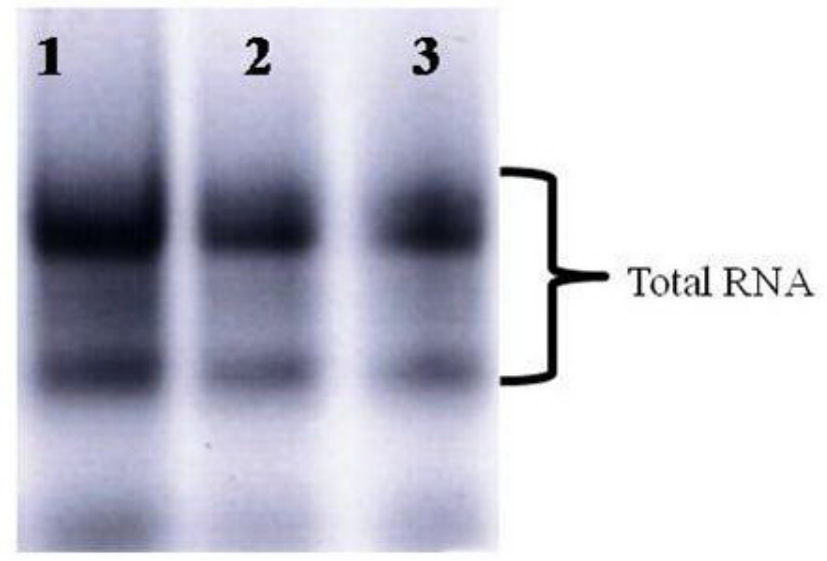

Figure 1. Gel electrophoresis of total RNA extracted from Euglena gracilis. Lanes 1 to $3=$ RNA isolated from Euglena gracilis.

To the best of our knowledge, there are no previous reports on RNA yields from $E$. gracilis, thus preventing a direct comparison. However, we can compare our findings with those reported from algae and plants rich in polysaccharides and polyphenols since they have similar complications during RNA isolation. E. gracilis RNA yields obtained by the use of SDS-phenol are similar to those reported for algal RNA by Cheong et al. (2004). On the other hand, with the aim of evaluating the suitability of the isolated RNA in downstream molecular procedures, total RNA was used for RT-PCR analysis (reverse transcription is highly sensitive to impurities), and as expected, $18 S$ ribosomal gene was amplified (Figure 2).

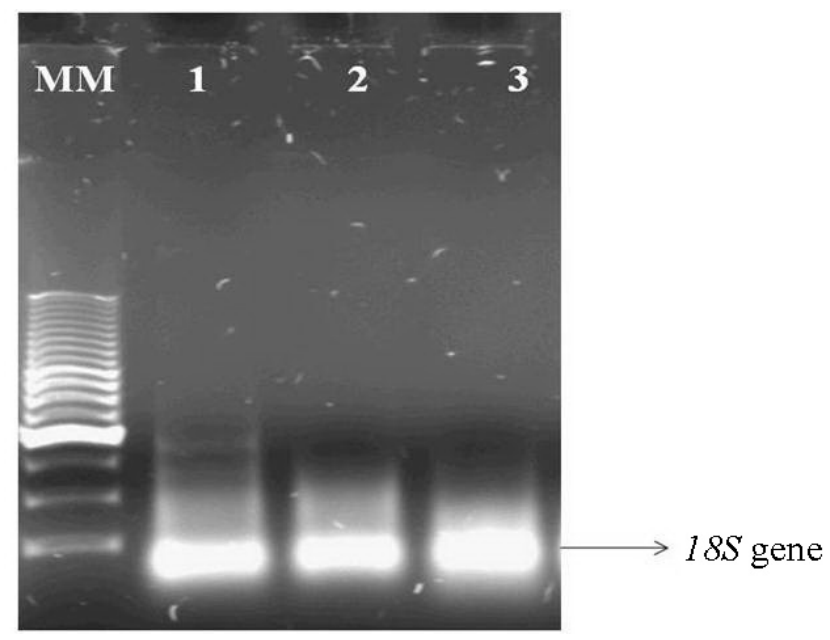

Figure 2. Agarose gel electrophoresis of the RT-PCR products. MM = DNA marker; lanes 1, 2, and $3=18 S$ gene, $300 \mathrm{bp}$. 
Owing to the chemical and biological diversities of free-living eukaryotic protists, until now, there is no universal RNA extraction method available. Thus, the current protocol is efficient and recommended for the isolation of good-quality total RNA from Euglenoids such as E. gracilis in less than $2 \mathrm{~h}$.

\section{ACKNOWLEDGMENTS}

The authors are particularly grateful to Dr. Takahiro Ishikawa (Shimane University) for donating the strain of Euglena gracilis used in this study. Research supported by a grant from CONACyT, No. 079234.

\section{REFERENCES}

Cheong XC, Swee-Sen T, Chai-Ling H, Rofina YO, et al. (2004). Optimisation of RNA extraction from Gracilaria changii (Gracilariales, Rhodophyta). J. Appl. Phycol. 16: 297-301.

Hutner SH, Bach MK and Ross GM (1956). A sugar-containing basal medium for B12 assay with Euglena; application to body fluids. J. Protozool. 3: 101-112.

MacDonald RJ, Swift GH, Przybyla AE and Chirgwin JM (1987). Isolation of RNA using guanidinium salts. Methods Enzymol. 152: 219-227.

Rodríguez-Zavala JS, Garcia-Garcia JD, Ortiz-Cruz MA and Moreno-Sánchez R (2007). Molecular mechanisms of resistance to heavy metals in the protist Euglena gracilis. J. Environ. Sci. Health A Tox. Hazard. Subst. Environ. Eng 42: 1365-1378.

Wang T, Zhang N and Du L (2005). Isolation of RNA of high quality and yield from Ginkgo biloba leaves. Biotechnol. Lett. 27: 629-633. 